\title{
Evaluation Of Water Quality At River Bian In Merauke Papua
}

\author{
Irba Djaja ${ }^{1, *}, P$. Purwanto $^{2}$ and $H . R$. Sunoko $^{3}$ \\ ${ }^{1}$ Doctoral Program of Environmental Science, School of Postgraduate Studies, Diponegoro University, Semarang Indonesia \\ ${ }^{2}$ Department of Chemical Engineering, Faculty of Engineering, Diponegoro University, Semarang Indonesia \\ ${ }^{3}$ Department of pharmacy, Faculty of Medical, Diponegoro University, Semarang Indonesia
}

\begin{abstract}
River Bian in Merauke Regency has been utilized by local people in Papua (the Marind) who live along the river for fulfilling their daily needs, such as shower, cloth and dish washing, and even defecation, waste disposal, including domestic waste, as well as for ceremonial activities related to the locally traditional culture. Change in land use for other necessities and domestic activities of the local people have mounted pressures on the status of the River Bian, thus decreasing the quality of the river. This study had objectives to find out and to analyze river water quality and water quality status of the River Bian, and its compliance with water quality standards for ideal use. The study determined sample point by a purposive sampling method, taking the water samples with a grab method. The analys is of the water quality was performed by standard and pollution index methods. The study revealed that the water quality of River Bian, concerning BOD, at the station 3 had exceeded quality threshold. COD parameter for all stations had exceeded the quality threshold for class III. At three stations, there was a decreasing value due to increasing PI, as found at the stations 1, 2, and 3. In other words, River Bian had been lightly contaminated.
\end{abstract}

\section{Introduction}

Use River Bian is one of the rivers situated in Merauke Regency, Papua Province, which has been included within the Bikuma River Stream (DAS Bikuma). The River Stream consists of Bian, Kumbe and Maro, covering a total area of approximately $9,493.80 \mathrm{~km}^{2}[1]$. The change in land use by a deforestation nearby DAS Bian for investment activities, such as plantation and industrial forest, has mounted a pressure on the River Bian. This change in land use has led to the decrease of the river water quality. The use of the river water for vary necessities should have been done sustainably. River is a very important ecosystem for human. It also provides water for many activities such as agriculture, industry, and domestic needs. Therefore, river resources must be protected in order to be used with a good practice by the human as well as other living creatures. River Bian plays a significant role for the Papuans, in particular the Marind, who live along the river. It has become a remarkable source for food materials (in forms of fish, shrimp, crab, etc., transportation media connecting between villages, and a place of traditional and cultural ceremonies for the local people [1].

Increasing domestic, agricultural, and industrial activities may affect the water quality of the river. In particular, domestic activities contribute to the largest BOD concentration to the river body (Minister of Environment Decree 115/2003) [2]. A river is considered having a decrease in water quality when it is no longer used according to a normal water quality status. The water quality status is the degree of water quality that proves a contaminated or non-contaminated conditions in a particular water source in a particular time comparable to the predetermined water quality threshold.

The determination of the water quality status is done, among others, by applying a Pollution Index Method. The Pollution Index is used for determining a pollution rate relative to a permissible water quality parameter. The Pollution Index (PI) is determined for a particular purpose, and then developed for some other purposes of the whole parts of the water body or parts of a river [2]. This study had purposes to analyze the river water quality and to find out water quality status of the River Bian before the change in land use from forestry to industrial (HTI) and its compliance with the water quality threshold as required.

\section{Research method}

This study applied a case study design by collecting primary data from the field. Information about water quality was obtained by collecting samples of water quality directly from the field at the observation points determined in each period from 2007 to 2015 . The water samples at the River Bian (DAS Bikuma) in Merauke, Papua, were taken from three observation points namely Bian upstream, Bian middle stream, and Bian

\footnotetext{
* Corresponding author: plhdjaja@gmail.com
} 
downstream, all situated in the area of the Industrial Forest (HTI).

The study used five broad categories of instruments, as follows: 1) $\mathrm{pH}$ meter and thermometer to calculate the $\mathrm{pH}$ and the temperature on locations; 2) media for samples; 3 ) icebox to preserve the samples; 4) Global Positioning System (GPS) to determine coordinate points of the sampling location (latitude, longitude, and elevation) on the map; and 5) writing devices to record the observation results.

The sampling points were determined by a purposive sampling technique, considering accessibility, cost, and time consumed during the research. The three sampling points of River Bian consisted of as the followings (Figure 1):

Station 1 : Bian Downstream (07054'45.6" S 140007 '23,9”N)

Station 2 : Bian Middle stream (07055'43.1''S 140007 '50" N)

Station 3 : Bian Upstream (07054'45.6's 140003 '42,4” N)

Sampling at the river water was performed by a grab sample technique. It was a direct sampling technique from the water body under the observation and only informed the water characteristics at the time the samples were taken [3]. Once the water sampling had been determined at each station, the samples collected were then subject to a laboratory test according to the predetermined standard. Treatments of the water samples consisted of labeling on each samples media), samples preservation (cooling or addition of chemical substances), and samples transportation (from the sampling stations to the laboratory). The samples preservation was intended to prevent them from any physical and chemical changes.

The river water quality test in this study was intended for $\mathrm{pH}$ and temperature parameters. The test was performed directly on the field using $\mathrm{pH}$ meter and thermometer. In case of TSS, DO, COD, BOD, phosphate, and nitrate parameters, the study performed a test at the Water Quality Laboratory Bandung. The water quality test was performed using a method pursuant to the ongoing standards. Table 1 contains the water quality testing method used in the current study.

The data collected from the physical and chemical parameters test of the river water, either on the field or in the laboratory, were then subject to a water quality analysis for the River Bian. The analysis was compared the test results to the class III water quality threshold pursuant to the Government Act 82/2001 on Water Quality Management and Water Pollution Control.

The water quality status was determined by using a Storet model with the following steps:

1. Water quality data collection in a periodical manner as such that it forms time series data.

2. Calculated data from each water parameter comparable to quality threshold by the water class.

The determination of the river water quality status in the current study applied a Pollution Index method [4] and used the following Pollution Index equation:

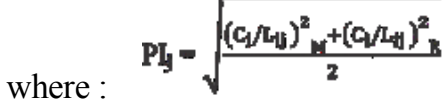

$\mathrm{Ij}:$ Concentration of water quality parameter recorded in the quality threshold for water ( $\mathrm{j}$ )

$\mathrm{Ci}$ : Concentration of water quality parameter (i)

PI : Pollution Index for purpose (j)

(Ci/Lij)M : Maximum value of $\mathrm{Ci} / \mathrm{Lij}$

$(\mathrm{Ci} / \mathrm{Lij}) \mathrm{M}$ : Average value of $\mathrm{Ci} / \mathrm{Lij}$

Results of the Pollution Index informed the degree of the pollution suffered by River Bian by comparing it to the quality threshold by the water class as required by the Government Act 82/2001. By doing so, valuable information is expected to determine whether the water in the river can be used for purposes according to its water class.

\section{Results and discussion}

\subsection{Analysis of water quality of River Bian}

The water quality analysis was performed to find out the use of the water for particular purposes by comparing it to the water quality by the water class. According to the purpose, River Bian was included in the class III. The observation results of the physical parameters (temperature and TSS) and the chemical parameters $(\mathrm{pH}$, DO, COD, BOD, phosphate, and nitrate) at each station were then compared to the class III water quality threshold [5]. The followings are the analytical results of each parameter:

\subsubsection{Temperature}

Figure 2 informs no significant difference in (or relatively stable of) the observation results of the water temperature parameters of the River Bian from 2007 to 2015 at each observation station.

The changing patterns of the temperature of the River Bian at the three observation points were generally stable, approximately 3 as compared to first conditions before the change in land use nearby the river. The average temperature at stations 1,2 , and 3, were 20.60 ${ }^{\circ} \mathrm{C}, 28.26{ }^{\circ} \mathrm{C}$, and $27.13{ }^{\circ} \mathrm{C}$, respectively. Compared to the water quality threshold of class III, which requires a deviation $(+3)$ of the natural condition6, the temperature parameter proved that the water quality of River Bian was still within the water quality threshold for its purpose.

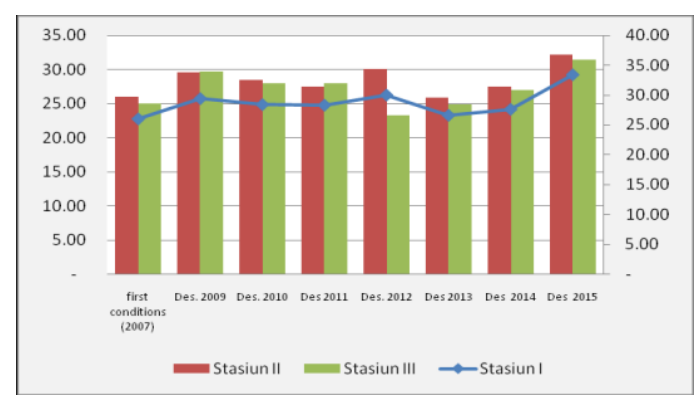

Fig 2. Temperatures of River Bian for the period of 2007-2015 
Figure 2 summarizes that the temperatures of all stations fluctuated, as compared to the early 2007 , ranging from 25 to $26{ }^{\circ} \mathrm{C}$. An increase then occurred in the following year with the deviation of +3 , with the highest deviation taking place in 20015 (4-5 degrees). The increasing temperature of the river in 2015 was triggered by the seasonal condition since 2015 had the longest summer.

\subsubsection{TSS (Total Suspended Solid)}

The TSS parameter at each station revealed an increase from the station 1 to the station 3 . The TSS value at the station was $222.13 \mathrm{mg} / \mathrm{l}$, decreasing at the station 2 to $78.60 \mathrm{mg} / \mathrm{l}$, and increasing at the station 3 to 165.18 $\mathrm{mg} / \mathrm{l}$. Therefore, compared to the class III water quality threshold under the Government Act 82/2001 (400 mg/l), the water quality condition of the River Bian was still in the water quality threshold for its purpose by the TSS.

The TSS was composed of muds and smooth sands as well as microorganisms, in particularly because of erosion carried to the water body [3]. In the river water, the source of the suspended solids is a run-off from the terrain nearby the river and the microorganisms weathering and animal corps carried by surface current to the water body. Writes that the suspended solids can decrease light intensity that absorbs into the water column, therefore disturbing growth and photosynthetic process of the vegetations living in this water area [5].

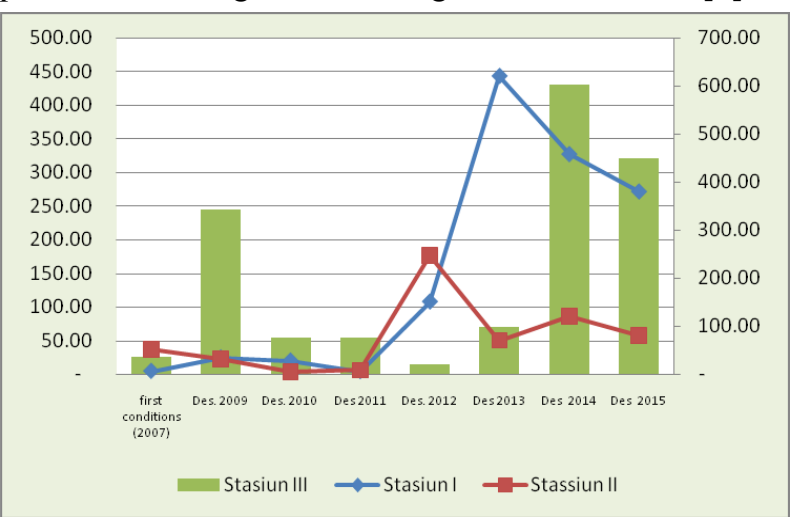

Fig 3. TSS of River Bian for the period of 2007-2015

The water TSS of River Bian at the stations 1 and 3 was high (Figure 3) because these stations were subject to deforestation for settlements, offices, power plant site, and industrial forest nearby the river flow. Suspended soils then inevitably formed by the run-off process. Furthermore, Table 2 contains the TSS for the fishery culture at the River Bian [6], 78.60-222.13 mg/l. These figures had caused the river not appropriate to the fishery activities [6].

Table 2. Appropriateness of the water for fishery purpose by the TSS

\begin{tabular}{ll}
\hline Grade TSS (mg/liter) & effect on interests of the fisheries \\
\hline$<25$ & no effect \\
$25-80$ & little effect \\
$81-400$ & unfavorable to interests of the fishery \\
$>400$ & not good for interests of the fishery \\
\hline
\end{tabular}

Source: Alabaster dan Lioyd, 1982

\section{$3.1 .3 \mathrm{pH}$}

The $\mathrm{pH}$ observation at each station revealed a fluctuative results from the station 1 to the station 3 . The $\mathrm{pH}$ at the stations 1, 2, and 3 were 7.39, 7.42, and 7.26, respectively. Compared to the $\mathrm{pH}$ required by the class III water quality threshold under the Government Act $82 / 2001$ (6-9), the water quality of the River Bian from the $\mathrm{pH}$ parameter was still within the water quality threshold for its purpose (Figure 4).

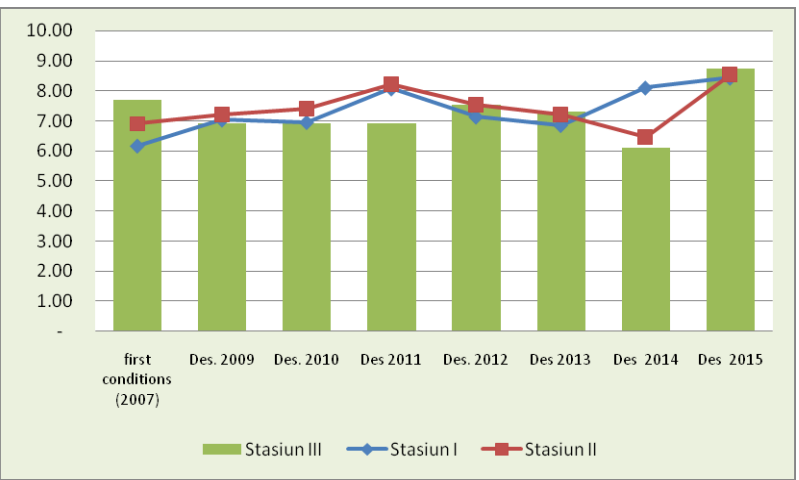

Fig 4. pH of River Bian for the period of 2007-2015

Figure 4 demonstrates that $\mathrm{pH}$ of the River Bian in the initial condition (2007) at the three stations ranged from 6.16 to 7.71 . These fluctuative $\mathrm{pH}$ values were due to the disposal of organic waste from domestic activities, vegetation and animal weathering, and waste as the byproduct of the industrial forestation nearby the River Bian. Besides, inorganic waste disposal also contributed significantly. However, the $\mathrm{pH}$ fluctuations did not significantly affect the river water quality. The normal water that fulfilled the requirements of a life system had a $\mathrm{pH}$ ranging from 6.5 to 7.5 [7]. The $\mathrm{pH}$ for the nonpolluted water traditionally is close to neutral $(\mathrm{pH} \mathrm{7)}$ and fulfills the needs of most aquatic organisms [8]. In conclusion, the River Bian was still an ideal habitat for the aquatic organisms because it contained $\mathrm{pH}$ of 7.267.43 .

\subsubsection{Biochemical Oxygen Demand (BOD)}

BOD is the amount of dissolved oxygen required by decomposing bacteria to decompose organic pollutants in the water. The higher the BOD concentration of an aquatic area, the higher organic materials concentration in the river water [9]. The higher BOD means the more severe pollution. Results of the BOD parameter observation revealed that a fluctuation occurred from the station 1 to the station 3. The average BODs at the station 1,2 , and 3 were $3.001 \mathrm{mg} / 1,2.84 \mathrm{mg} / 1$, and 4.13 $\mathrm{mg} / \mathrm{l}$, respectively. Pursuant to the Government Act $82 / 2001$, the class III water quality threshold for the BOD parameter is $6 \mathrm{mg} / \mathrm{l}$. Compared to the observation results of the River Bian water quality, the water quality condition at the station 1 was still within the quality threshold, but at the stations 2 and 3 it had exceeded for its purpose. 


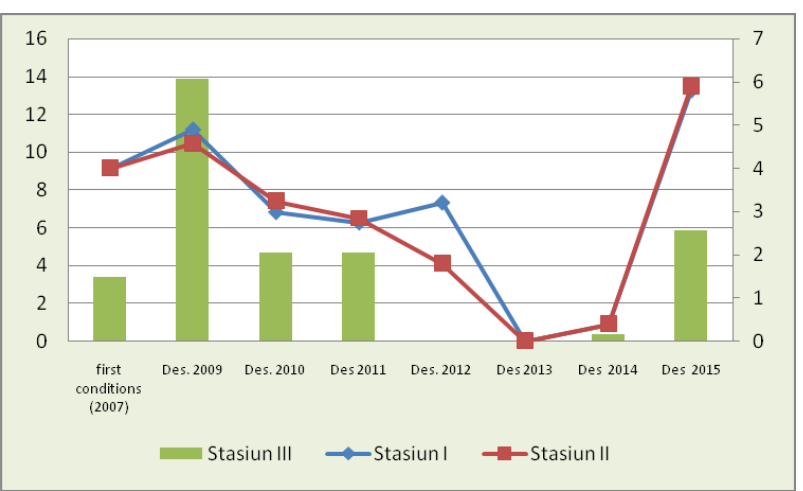

Fig 5. BOD of River Bian for the period of 2007-2015

Figure 5 shows an increase in the BOD content in 2009 at the station III, exceeding the class III quality threshold (quality threshold 6). It was because in 2009 there was a deforestation for development area. Contend that the increase in the BOD can be due to organic materials from the domestic and other wastes [10]. The high BOD is believed to be due to waste disposal from the settlements and from the agricultural fields to the river [6]. The Figure 5 also exposes that the water quality of the River Bian was still within the threshold but the higher BOD from the upstream to the downstream signed a polluted water area due to the domestic and agricultural waste disposal.

\subsubsection{Chemical Oxygen Demand (COD)}

COD is the amount of the oxygen needed to oxidize organic materials chemically [9]. The observation results of the BOD content at each station proved a decrease from the station 1 to the station 3 . The average COD at the stations 1,2 , and 3 were $20.34 \mathrm{mg} / 1,25.82 \mathrm{mg} / 1$, and $42.43 \mathrm{mg} / \mathrm{l}$, respectively. Compared to the class III water quality threshold for the COD parameter pursuant to the Government Act 82/2001 (50 mg/l) the water quality condition of the River Bian for the stations 1, 2, and 3 was still within the water quality threshold for its purpose.

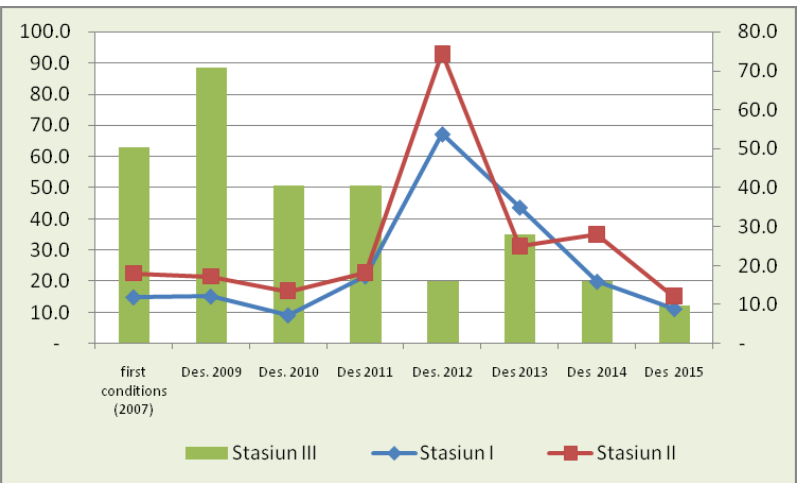

Fig 6. COD of River Bian for the period of 2007-2015

Figure 6 summarizes an exceeding rate of the initial COD (as of 2007) at the station and a further increase by 2009. The high COD indicated the more pollutants found in the water body [9]. The increase in COD at the River Bian was caused by the change in land use/deforestation for investment, where the by-products and the waste were found nearby the river. Aquatic area with high
COD is no longer suitable for fishery or agricultural purposes. The COD in the non-polluted water is generally less than $20 \mathrm{mg} / \mathrm{l}$, whereas in the polluted water the rate can rise more than $200 \mathrm{mg} / \mathrm{l}$ [3]. The COD tends to decrease over the years after the deforestation. Therefore, the water quality of the River Bian for the COD parameter was still supportive for the fishery and agricultural purposes.

\subsubsection{DO}

Dissolved oxygen (DO) can be used as an indicator of the water freshness [8]. The oxygen plays an important role as a quality indicator in the water because DO helps oxidation and reduction processes of both organic and inorganic materials. Because of oxidation and reduction processes the DO becomes significant to help ease the pollution burden in the water naturally [11].

The results of the DO parameter observation at each station proved fluctuative rates from the station 1 to the station 3, as it might be seen from the DO at the station 1 (4.65 mg/l), station $2(4.63 \mathrm{mg} / \mathrm{l})$, and station 3 (4.67 $\mathrm{mg} / \mathrm{l})$. Compared to the class III water quality threshold for the DO parameter pursuant to the Government Act $82 / 2001$ (3 $\mathrm{mg} / \mathrm{l}$ ), the water quality condition of the River Bian at all stations had been exceeding the minimum requirement for its purpose.

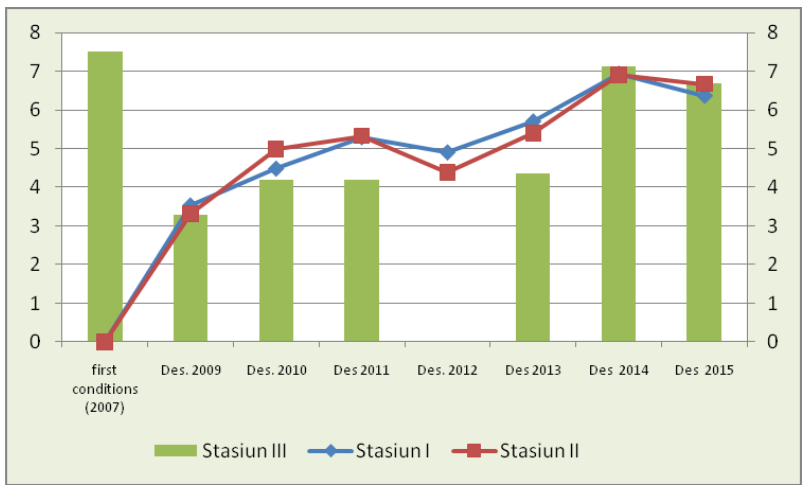

Fig 7. DO of River Bian for the period of 2007-2015

Generally, the study only found a small proportion of the polluted water. The more organic disposal waste causes the lower content of the dissolved oxygen in the water [12]. Human activities such as agricultural and waste disposal have caused the decreasae in the dissolved oxygen [13]. The decrease in the BOD of River Bian at each station was an accumulation of the waste disposal from the domestic and agricultural activities nearby the river. Water can be categorized good with a low pollution if the dissolved oxygen content is $>5 \mathrm{mg} / \mathrm{l}$ [11]. The study indicated that the water quality of the River Bian for the DO parameter had a low pollution rate.

\subsubsection{Phosphate}

The observation of the phosphate parameter at each station showed a decrease from the station 1 to the station 3 , as it might be proven by the phosphate content of the stations $1,2,3$, which steadily decreased from 
$0.22 \mathrm{mg} / 1$ to $0.20 \mathrm{mg} / 1$ to $0.19 \mathrm{mg} / \mathrm{l}$. compared to the phosphate content of the class III water quality threshold pursuant to the Government Act 82/2001 (1 mg/l), the water quality condition of the River Bian from the phosphate parameter was still within the water quality threshold for its purpose.

Phosphate is a phosphorus variant, which can be valuable for vegetations. Its characteristics are very different from the other substances as it can help form biosphere and it is not available in the atmosphere [3]. In agricultural area phosphate is produced from fertilizers absorbed in the river through drainage and rainfall waterflow [14]. Even though whole part of the River Bian was subject to the agricultural activities, the phosphate rate at each station was proven low (Figure 8). It was probably due to a natural dissolution along the River Bian so that the concentration of the pollutants decreased. This natural recovery process, both totally or partially, helped the river to reclaim itself and to perform a self purification [12].

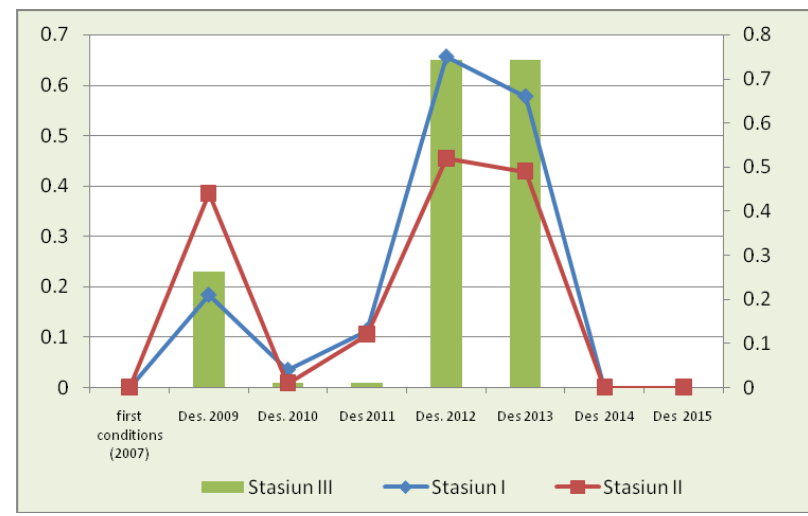

Fig 8. Phosphate of River Bian for the period of 2007-2015

\subsubsection{Nitrate}

Nitrate (NO3) is the main form of nitrogen in natural waters and is the major nutrient for the growth of vegetations and algae. The nitrogen nitrate is water dissolved and stable. This compound is derived from a complete oxidation process of the nitrogen in the water [15]. Nitrate is a stable compound and is derived from the disposal of the agricultural activities, fertilizers, and composes [14]. The study observation resulted in an increase in the nitrate content from the station 1 to the station 3, as it was proven by the average nitrate at the stations 1, 2, and 3 of $2.21 \mathrm{mg} / 1,2.57 \mathrm{mg} / \mathrm{l}$, and $3.97 \mathrm{mg} / 1$, respectively. Figure 9 shows a fluctuative rate of the nitrate, where a drastical increase occurred in 2012 and 2013. However, the increase was still below the quality threshold. The class III water quality threshold pursuant to the Government Act 82/2001, the maximum rate of the nitrate parameter required is $20 \mathrm{mg} / \mathrm{l}$. therefore, compared to the water quality condition, the River Bian was still within the water quality threshold for its purpose albeit the factual condition proved vary activities found along the river, including defecation and waste disposal. It was possibly due to a dissolution process along the river.

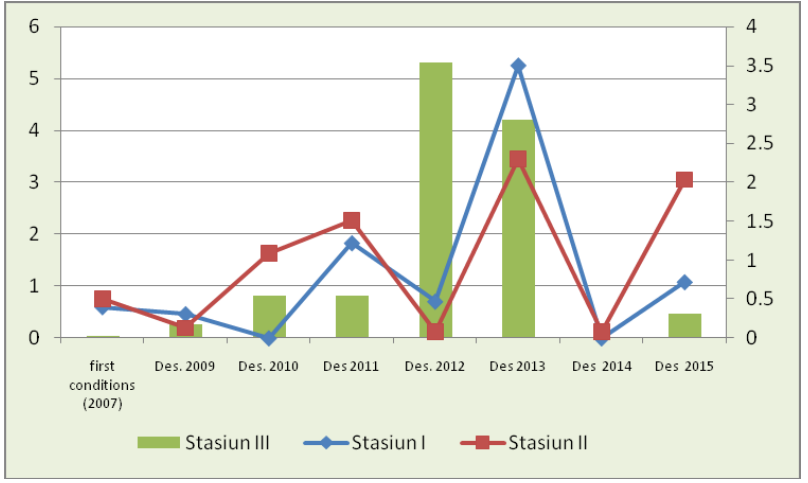

Fig 9. Nitrate of River Bian for the period of 2007-2015

\subsection{Analysis of water quality status of River Bian}

Water quality status is a degree to which the water quality condition indicates either pollution or nonpollution in particular water source and particular time as comparable to the predetermined water quality threshold. In this study the parameters used for the analysis of the water quality status were TSS, pH, CO, COD, BOD, phosphate and nitrate. The legal parameter used was class III water quality threshold pursuant to the Government Act 82/2001.

Table 3. Correlation of IP to Water Quality Status

\begin{tabular}{|l|l|}
\hline Pollution Index & Water Quality \\
\hline $0 \leq \mathrm{PIj} \leq 1,0$ & $\begin{array}{l}\text { Good condition (fulfilling quality } \\
\text { threshold) }\end{array}$ \\
\hline $1,0<\mathrm{PIj} \leq 5,0$ & Light pollution \\
\hline $5,0<\mathrm{PIj} \leq 10,0$ & Moderate pollution \\
\hline $\mathrm{PIj}>10,0$ & Severe pollution \\
\hline
\end{tabular}

Source : Government Act 82/2001

The analysis of the water quality status was performed according to a case determination of the water quality status as required [16], using a Pollution Index method. The calculation of the water quality status of the River Bian using the PI method is summarized in Table 3 below. The calculation revealed that the water quality of the River Bian from the upstream to the downstream at three observation stations tended to increase as marked by the decrease in the PI. The water quality status at the station $1(\mathrm{PI}=1.61)$, station $2(\mathrm{PI}=1.63)$, and station $3(\mathrm{PI}=1.82)$ proved that the river was in a "moderate pollution status". Therefore, the water quality of the River Bian at the stations 1, 2, and 3 could still be utilized according to the class III water purpose (freshwater fishery culture, farm, irrigation, and other related purposes). These results proved that the investment activities did not mount any pressure on the water quality of the River Bian. The local people who 
live nearby the river would still be able to make use of the water for their daily needs.

\section{Conclusion}

1. Water quality of River Bian according to BOD and COD parameters at three stations had exceeded the quality threshold for the class III.

2. Water quality status of River Bian at the stations 1 and 2 proved a "moderate pollution status".

\section{References}

1. Laporan Status Lingkungan Hidup Kabupaten Merauke tahun 2007. BLH Kabupaten Merauke. (2007)

2. Kementerian Lingkungan Hidup. 2003. Keputusan Menteri Negara Lingkungan Hidup Nomor 115 Tahun 2003 tentang Pedoman Penentuan Status Mutu Air. Kementrian Lingkungan Hidup Republik Indonesia, Jakarta. (2003)

3. H. Effendi, Telaah Kualitas Air bagi Pengelolaan Sumberdaya dan Lingkungan Perairan. Penerbit Kanisius. Yogyakarta, (2003)

4. Kementerian Lingkungan Hidup. Peraturan Pemerintah Republik Indonesia Nomor 82 Tahun 2001 tentang Pengelolaan Kualitas Air dan Pendendalian Pencemaran Air. Kementrian Lingkungan Hidup Republik Indonesia, Jakarta. (2001)

5. S. M. Haslam, River Pollution: An Ecological Perspective. John Wiley and Sons. Chichester. 253 $\mathrm{h},(1990)$

6. Alabaster, JS and R. Lloyd. Water Quality Criteria for Freshwater Fish. Second Edition. Food and
Agriculture Organization of United Nations by Butterworths. London, (1982)

7. W.A. Wardhana, Dampak Pencemaran Lingkungan. Penerbit Andi, Yogyakarta, (2004)

8. A. Sutriati, Jurnal Sumber Daya Air, 7. 61-76, (2011)

9. S. Yudo, Kondisi Kualitas Air Sungai Ciliwung di Wilayah DKI Jakarta Ditinjau Dari Parameter Organik, Amoniak, Fosfat, Deterjen dan Bakteri Coli. Pusat Teknologi Lingkungan, Badan Pengkajian dan Penerapan Teknologi (BPPT), Jakarta. Hal: 1-9, (2010)

10. S. Rahayu, and Tontowi. "Penelitian Kualitas Air Bengawan Solo Pada Saat Musim Kemarau". Jurnal Sumber Daya Air, 5. 127-136, (2009)

11. Salmin, Jurnal Oseana, 30. 21-26, (2005)

12. R. Vagnetti, P. Miana, M. Fabris and B. Pavoni, Jurnal of Chemosphere, 52. 1781-1795, (2003)

13. B.A. Anhwange, E. B. Agbaji, and E.C. Gimba,: International Journal of Science and Technology, 2(5):248-254, (2012)

14. I.N.A. Winata, A. Siswoyo, and T. Mulyono, Jurnal Ilmu Dasar, 1. 24-28, (2000)

15. K.K. Blume, J.C. Macedo, A. Meneguzzi, L.B. Silva, D.M. Quevedo, and M.A.S. Rodrigues. Journal of Biology, 70. 1185-1193, (2010)

16. Kementerian Lingkungan Hidup. Keputusan Menteri Negara Lingkungan Hidup Nomor 115 Tahun 2003 tentang Pedoman Penentuan Status Mutu Air. Kementrian Lingkungan Hidup Republik Indonesia, Jakarta. (2003) 